b) - Aos atuais professores e funcionarios da Flaculdade são garantidos, pelo govêrno federal, os direitos e as vantagens que as leis federais lhes asseguram, inclusive o pagamento dos respectivos vencimentos, pelo Tesouro Federal, sem embargo de outros direitos que as leis estaduais outorguem a professores e funcionarios de igual categoria;

c) - Os professores e funcionarios, que forem nomeados para a Faculdade, posteriormente á data deste decreto, terão os seus direitos e deveres regulados pelas leis estaduais;

d) - A organização didatica, o regime escolar, a nomeação do diretor e do pessoal docente e administrativo da Faculdade passarão a obedecer as disposições estatutarias da Universidade de São Paulo.

Art. 3.' - Em caso de extinção da Universidade, a Faculdade de Direito em São Paulo reverterá, com o respectivo patrimonio, para o govêrno da União.

$\S$ - unico - A reversão poderá, igualmente, ser realizada quando o exijam os interesses do ensino.

Art. 4. ${ }^{\circ}$ - Enquanto os estatutos da Universidade de São Paulo não forem aprovados pelo govêrno federal, a Faculdade de Direito, ora transferida, continuará a ser administrada e regida pelas leis e regulamentos federais.

Art. 5." - O govêrno do Estado, salvo o disposto no art. 2.", letra “B”, proverá o custeio da Faculdade.

Art. 6..$^{\circ}$ - O presente decreto entrará em rigor na data de sua publicação, revogadas as disposições em contrario.

Rio 'de Janeiro, 10 de Abril de 1934, 113.' cla Independencia e $460^{\circ}$ da Republica

$$
\begin{aligned}
& \text { (aa) - Gretulio Vargas } \\
& \text { Washington Pires }
\end{aligned}
$$

\title{
Decreto n. 6.429, de 9 de Maio de 1934
}

Aprova o Regulamento da Faculdade de Direito de São Paulo.

O DOUTOR ARMANDO DE SALLES OLIVEIRA, Interventor Federal no Estado de São Paulo, usando das atribuições que lhe confére o decreto federal n. 19.398, de 11 de novembro de 1930; e

Considerando ter o Govêrno da União, pelo decreto n. 24.102, de 10 de abril do corrente ano, transferido ao Estado de São Paulo a Faculdade de Direito para ser incorporada á Universidade criada pelo decreto n. 6.283, de 25 de janeiro de 1934; 
Considerando que o Regulamento da Faculdade de Direito aprovado pelo Concelho Nacional de Educação, ainda não fôra expedido por decreto do Govêrno Federal;

Considerando a necessidade de um regulamento para normalizar o funcionamento da Faculdade dentro das leis federais do ensino;

\section{Decreta :}

Artigo $10^{\circ}$ - Fica a Faculdade de Direito de São Paulo, nos termos do decreto federal n. 24.102, de 10 de abril de 1934, incorporada á Universidade de São Paulo.

Artigo 2." - Sem prejuizo das modificações que vierem a ser adotadas pelos Estatutos da Universidade de São Paulo, vigora, com fôrça de lei, o Regulamento da Faculdade de Direito, que com êste baixa, assinado pelo Secretario da Educação e da Saude Publica.

Artigo 3." - Consideram-se suprimidos, na Faculdade de Direito, os cargos não mencionados no mesmo Regulamento.

Artigo 4. - Todos os atuais funcionarios da Faculdade continuam a receber da Uniāo, nos termos do decreto federal n. 24.102, de 10 de abril de 1934, os respectivos vencimentos.

$\S 1 .^{\circ}$ - Os atuais funcionarios, cujos cargos ficaram suprimidos, e forem aproveitados em outros, perceberão do Tesouro do Estado a diferença entre os vencimentos do cargo novo, e os do anterior, os quais continuam a ser pagos pela União.

$\S 2$. - Os atuais funcionarios, cujos cargos ficaram suprimidos na forma do artigo 2.' dêste decreto, e não forem aproveitados em outros cargos, ficarão adidos á Faculdade e obrigados aos serviços que lhes forem designados pelo Diretor.

$\S 3 .^{\circ}$ - Os atuais funcionarios, cujos cargos não ficaram suprimidos, perceberão no Tesouro do Estado a diferença entre os vencimento santeriores e os fixados por êste decreto.

Artigo 5." - São êstes os vencimentos anuais do pessoal administrativo da Faculdade:

Secretario

$16: 800 \$ 000$

Tesoureiro

$15: 600 \$ 000$

Chefe técnico da bibliotéca

$15: 600 \$ 000$

Auxiliar do Secretario (Chefe de Secção)

$14: 400 \$ 000$

Secretário da Revista (gratificação). ..

$4: 800 \$ 000$

Chefe de Secção

$14: 400 \$ 000$

Primeiro escriturario

$12: 000 \$ 000$

Segundo escriturario

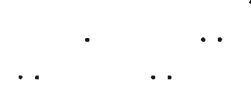

9:600\$000

Terceiro escriturario

$7: 200 \$ 000$

Quarto escriturario

Contador

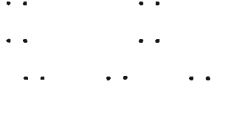

$6: 000 \$ 000$

$9: 600 \$ 000$ 
Auxiliar do chefe técnico da bibliotéca

$9: 600 \$ 000$

Porteiro

.. . .

$7: 200 \$ 000$

Bedel

.. .

$5: 400 \$ 000$

Continuo

$4: 800 \$ 000$

Encadernador (contratado)

$2: 400 \$ 000$

Ascensorista

$3: 750 \$ 000$

Servente

$3: 750 \$ 000$

Artigo 6. - No orçamento anual do Estudo consignar-se-á verba para pagamento de todas as despesas da Faculdade, que não tiverem ficado a cargo da União, excetuadas as despesas com a regencia de turmas desdobradas as quais serão pagas pelos cofres da Faculdade.

$\S 10^{\circ}$ - Durante o corrente exercicio, as despesas cabiveis ao Estado serão pagas pelos cófres da Faculdade, e a êstes restituidos pelo Tesouro do Estado, com verba que se consignará no proximo orçamento.

$\S 20^{0}$ - Para efeito da restituição referida no parágrafo anterior, o Diretor da Faculdade enviará ao Secretario da Educação, no mês de dezembro do corrente ano, a competente relação da despesa.

Artigo $7 .^{\circ}$ - Para fins de consignação orçamentaria, o Diretor da Faculdade enviará ao Secretario da Educação, no mês de outubro de cada ano, a proposta do orçamento da Faculdade para o ano seguinte, elaborado pelo Concelho Técnico-Administrativo, na fórma do Regulamento.

Artigo $80^{\circ}$ - Este decreto entra em vigor na data de sua publicação, revogadas as disposições em contrario.

Palacio do Govêrno do Estado de São Paulo, aos 9 de maio de 1934 .

armando de Salles Oliverra

Christiano Altenfelder Silva.

Publicado na Secretaria de Estado da Educação e da Saude Publica, em 9 de maio de 1934.

\section{A. Meirelles Reis Filho}

Diretor Geral. 